\title{
野生動物の安楽死（安楽殺処分）
}

\author{
淺野 玄 \\ 岐阜大学応用生物科学部 干 501-1193 岐皁市柳戸 1-1
}

\section{Euthanasia of Wildlife}

\author{
Makoto ASANO \\ Faculty of Applied Biological Sciences, Gifu University1-1 Yanagido, Gifu 501-1193, Japan
}

\begin{abstract}
Euthanasia is the death that occurs with minimal or no pain. Although the regulation about humane killing of animals is established by Act on Welfare and Management of Animals in Japan, but the act is intended for animals under the control of human, such as pet animals, zoo and aquarium animals, livestock, and laboratory animals. The act that specifies the humane killing of wildlife has not been fixed yet. However, actually for example in the population control for various damages mitigation, control of invasive alien species, wildlife rescue and research, there are many situations that needs killing of wildlife. In order to not only relieve the mental stress and social pressure experienced in taking lives of animals but achieve the accountability for euthanasia of wildlife, a method that minimizes as much as possible the pain and distress to the animal should be used. It is desired for the future maintenance of the guidelines on euthanasia of wildlife and developing the education and training of experts.
\end{abstract}

Key words : euthanasia, guidelines, wildlife

Jpn. J.Zoo. Wildl.Med. 15(1): 5-8, 2010

\section{はじめに}

安楽死とは，「苦痛がない，または苦痛が最小限である死」 であり, 人道的に安楽死を誘致する行為が安楽殺処分である。 わが国では，「動物の愛護及び管理に関する法律」（動物愛護管 理法）(昭和 48 年 10 月 1 日法律第 105 号, 平成 17 年一部 改正）の中で，「動物を殺さなければならない場合には，でき る限りその動物に苦痛を与えない方法によってしなければなら ない」と人道的な殺処分に関する規定がなされている。さらに, 「環境大臣は, 関係行政機関の長と協議して, 前項の方法に関 し必要な事項を定めることができる」としている。この法律の 趣旨に従って，「動物の処分方法に関する指針」(平成 7 年総理 府告示第 40 号）が定められ，殺処分に関する基準が示されて いる。また, 社団法人日本獣医師会によって「動物の好分方法 に関する指針の解説」が刊行されている [1]。この解説にお ける処分の原則は, 動物に不必要な不安, 恐怖, 苦痛を与える ことなく, 一刻も早く意識を喪失させ, 非可逆的な心機能ある いは肺機能の停止をもたらすことである [1]。ここでいう苦 痛の意義は, 痛覚刺激による痛み並びに中枢の興奮などによる 苦悩, 恐怖およびうつの状態などの態様と定義されている $[1]$ 。 さらに, この解説では, 理想的かつ具体的な殺処分法に関する
記載もなされている。

ところで, 動物愛護管理法で対象としているのは, 家庭動物, 展示動物, 産業動物 (畜産動物), 実験動物などの人の飼養に 係る動物である。動物の処分方法に関する指針では,「対象動 物以外の動物を処分する場合においても，この指針の趣旨に沿 って配慮するよう努めること」とされるにとどまっている。一 方, 2005 年 6 月より施行された外来生物法でも, 特定外来生 物をやむを得ず処分しなければならない場合には，できる限り 苦痛を与えない適切な方法で行うことと定めているが，当然の ことながら在来野生動物種はこの法律の対象ではない。つまり, わが国には野外で生息している野生動物を保護する法律は多く あるが，その殺処分について定める法律が整備されてこなかっ たというのが実情である。しかし，現代はいかなる理由があっ ても動物の命を奪うべきではないという感情的な愛護思想だけ では, 複雑かつ多様化する野生動物問題は解決し得ない時代を 迎えており，野生動物の殺処分が必要な場面は多い。また，野 生動物の処分は社会の注目を集めることが多く, 野生動物も含 めた動物の安楽殺（安楽殺処分）に関するガイドラインの整備 がわが国でも望まれる。

本論は, 野外に生息する野生動物の安楽殺処分に関するガ イドラインの整備に向け, わが国の現状と課題を筆者の経験 
を踏まえながら整理することを試みた。なお，本論で引用し ている米国獣医学会による 2000 Report of the AVMA Panel on Euthanasia（安楽死に関する研究会報告 2000） [2], AVMA Guidelines on Euthanasia（安楽死に関するガイドライン） [3] には，野生動物の推奨されるべき具体的な安楽殺処分法も言及 されており，安楽殺処分を実施している獣医師や作業者にとっ て極めて有益な資料である。2000 Report of the AVMA Panel on Euthanasia は，日本獣医師会雑誌第 58 巻（2005） 5 号か ら 12 号にて解説・報告として日本語で紹介されているので, 合わせて参照されたい。

\section{野生動物の保護に関わる法律}

法律上は無主物とされる野生動物の保護に関わる法律は多く あるが，代表的なものには，(1)鳥獣の保護や狩猟の適正化を目 的とした鳥獣保護法, (2)絶滅のおそれのある野生動植物種の保 存を目的とした種の保存法, (3)特に学術上の価値の高い種を保 存するための文化財保護法, (4)自然環境の保全を目的とした自 然環境保全法, (5)優れた自然の風景地を保護し利用することを 目的とした公園法, (6)漁業調整機構の運用によって水面を総合 的に利用することを目的とした漁業法などがあり [4]，原則 的にそれぞれの法律で保護の対象とされる野生動物の捕獲や殺 処分などは厳しく規制されている。しかし, 現実的には, 獣医 学的あるいは生態学的にみて殺処分が妥当であると判断される ケースは少なくはなく，このような現実と保護を目的としたさ まざまな法律の適用・運用や解釈とのギャップで問題が生じて いる。

\section{野生動物の処分が検討されるケース}

動物愛護管理法においては，動物をみだりに殺し，傷つけ，

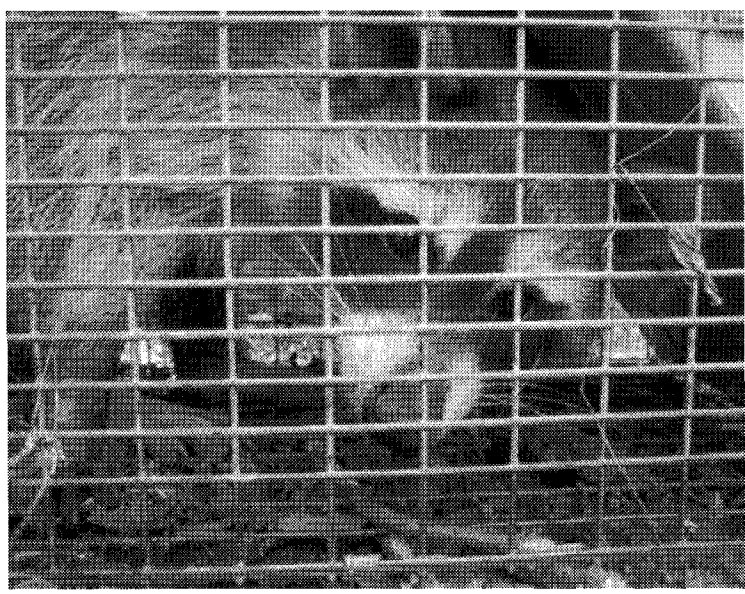

図 1 箱罩で捕獲された特定外来生物のアライグマ
または苦しめることは禁じられている。一方，動物の処分方法 に関する指針の解説では，以下の 4 つのようなやむを得ない 事例では動物を致死させること（処分）ができるとしている。

事例 1 重篤な疾病あるいは障害によって回復の見込みがな

く，かつ，著しい苦痛を伴っていて，致死以外に方法がな い場合

事例 2 動物集団の維持のためには生存数の人為的調節以外 に方法がない場合

事例 3 人の生存および生活が脅かされ，あるいは将来脅か されると予測され，動物を致死させる以外に方法がない場 合

事例 4 その動物の利用目的が致死によって完結する場合 である。

前述の通り, 動物愛護管理法の対象としているのは人の飼養 に関わる動物であるが，野生動物においても殺処分が検討され るべき状沉がある。例えば，個体数の過㮃な増加などにより， 生態系, 農林水産業や生活環境に被害を及ぼす野生動物個体群 は，被害防除対策とともに被害軽減のための個体数調整，すな わち捕獲・殺処分が選択される。その理由の 1 つとして, 被 害軽減目的の個体数調整の場合は多数の加害個体が対象である ことが多く, 全ての加害個体を隔離または被害地域から捕獲・ 移動させることは非現実的であることがあげられる。殺処分を 実施する際には, 動物種, 個体数, 保定法, 実施者の技術など のさまざまな条件を考慮し, 最適な安楽殺処分法を選択する必 要がある。殺処分を伴う個体数調整では，捕獲個体分析などに より対象動物の個体群動態をモニタリングし，個体数管理政策 にフィードバックすることが重要である。

また，回復の見込みがない救護動物についても，殺処分が検

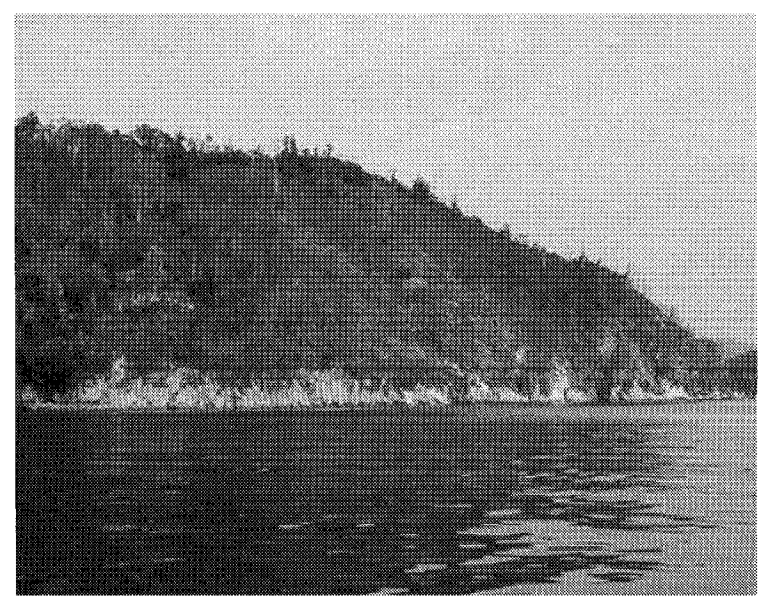

図 2 カワウの営巣による深刻な植生被害を軽減するために駆 除が行われている竹生島（滋賀県） 


\section{野生動物の安楽死（安楽殺処分）}

討されることがある。著者が所属する岐阜大学には，附属の野 生動物救護施設がある(現, 附属野生動物管理学研究センター)。 当センターには，特別天然記念物のライチョウからツバメやス ズメといった普通種，さらには原則として救護の対象にしてい ない特定外来生物のアライグマも搬入されることがある [5]。 多くの救護施設では, 搬入種の $8 \sim 9$ 割は鳥類であり, 治療 やリハビリテーションを行っても，放野されるものは $3 \sim 4$ 割程度にとどまっていると思われる。巣立ち雛の䛊認救護や落 巣雛を除けば, 救護動物の多くは車, 空ガラス, 電線などの人 工物への衝突が原因で，獣医学的にみて整復不可能な機能障害 や骨折などの外傷を伴っている [5]。断翼や断脚術などによ って技術的に救命することは可能であるケースも多いが，野生 動物に施術をして障害を持たせたまま終生飼育することは，動 物福祉の観点からも好ましいとは考えがたい。加えて, 救護施 設には，救命した動物を全て飼育する “余裕”はなく，動物福 祉に配慮した環境を維持して長期飼育することは不可能である う。このような観点から, 当センターでは, 「野生復帰が困難 な傷病鳥獣の取り扱い指針 (案)」を策定し, 獣医学的・生態 学的に野生復帰不可能であると複数のスタッフによって判断さ れた動物は，原則として永久飼育をしていない（一部例外を除 く)。すなわち, 獣医師が麻酔薬の過剩投与により安楽殺処分 を行っている。しかし，種の保存法や文化財保護法などにおけ る保護対象種は，これらの法律の趣旨から救護個体の殺処分が 想定されていないため,「回復の見込多がなく，かつ，著しい 苦痛を伴っていて, 致死以外に方法がない」と獣医学的に判断 されても法律上は殺処分が認められていない。その結果，苦痛 を伴いながら死亡するのを見とどけなければならないという,

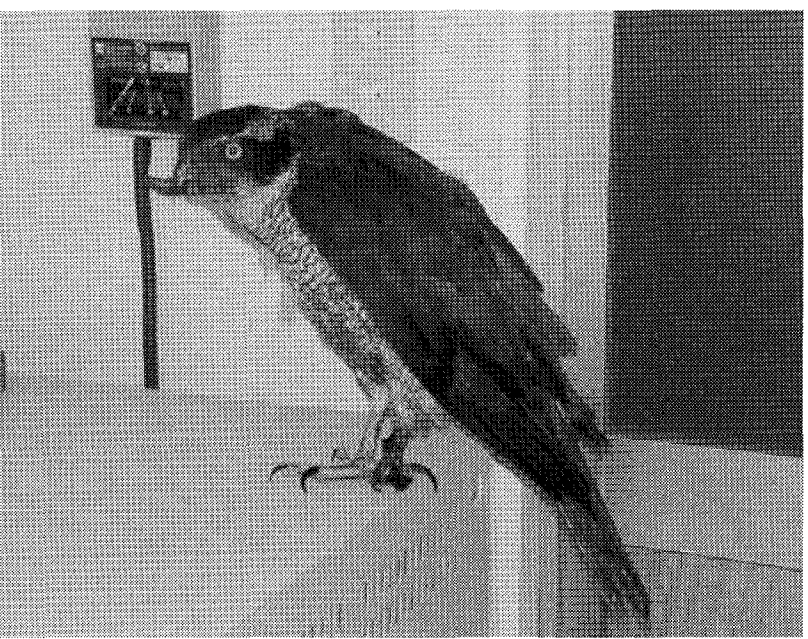

図 3 事故で左脚が切断された種の保存法における保護対象種 のオオタカ
動物福祉に逆行する状況が生じている [6]。稀少種の保存には 個体の保護がきわめて有益ではあるが，法律の保護対象種であ つても個体の死が不可避, QOL の著しい低下が明らか, 生息 域外保全のファウンダーとして不適合であるような救護個体に ついては, 絶滅リスクとの整合性を考慮し, 安楽殺処分の検討 もなされるべきであるう。

また，野生動物調査においては，学術的な目的がその動物の 致死によってのみ達成されると適切に判断され，かつ，必要な 許可申請を行うことによって, 致死調査が認められる。野生動 物の致死調査を行う研究者は，適切な技術や知識を有している 獣医師などの協力を得て，調査目的と合致した安楽殺処分法を 検討することが必要である。

\section{野生動物の安楽殺処分法の選択}

米国獣医学会（2001）では，安楽殺処分は速やかに意識を 消失させ，続いて心肺機能の停止および最終的な脳機能の停止 を生ずる必要があるとしている [2]。しかし，人の管理下に あって保定が可能な動物で推奨される安楽殺処分法は，野生動 物では実施できない場合が多い。そもそも，保定ができない状 況もあるうえに，捕獲・保定・輸送そのものが野生動物には多 大なストレスであるため, “苦痛なく”死に至らしめることは 困難である。また, 動物種, 大きさ, 個体数, 作業者の数, 実 施者の技量, 利用できる薬剤や道具の種類と安全性, 処分個体 が肉食・腐食動物に捕食される可能性, 環境への薬剤残留, な どの条件によって殺処分法が限定される。しかし，命を奪うこ との精神的ストレスや処分に対する社会的圧力に耐え,科学的・ 論理的に安楽殺処分に対する説明責任を果たすためには，い

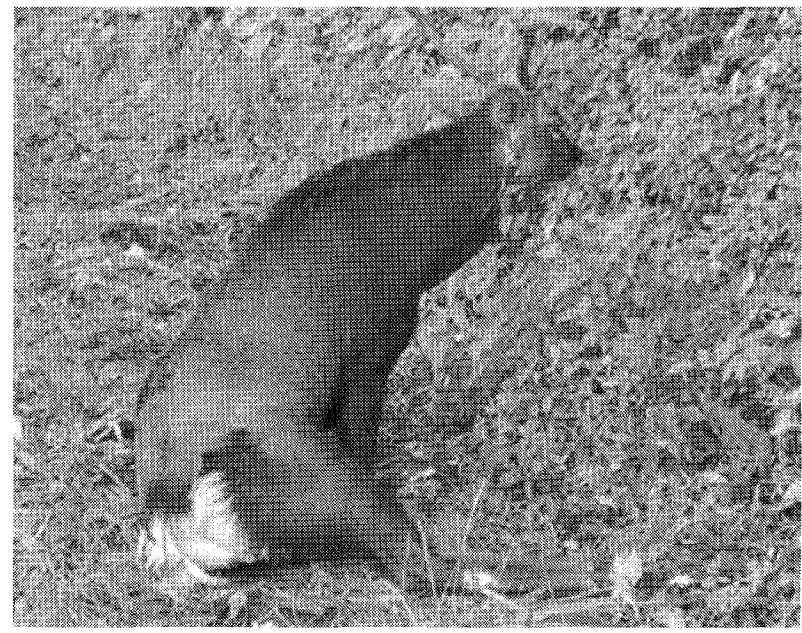

図 4 交通事故による後躯不全麻痺のために安楽殺処分された ニホンジカ 
かなる状況下であっても選択し得る方法の中で動物への苦痛が 最小限の殺処分法で実施するという原則の遵守が不可欠であろ 引。

\section{おわりに}

これまで述べたように, わが国では野生動物の安楽殺処分を 規定する法律やガイドラインの整備が不十分である。しかし， 現実的には, 安楽殺処分が必要な場面は増加しており, その職 能を有している専門家として社会から認識されている獣医師に は, 最適な処分法を実行する技術力や知識が求められている。 すなわち, 安楽殺処分の実施は, 獣医師の社会的責務であり, トレーニングや知識の収集を急ってはならない。また, 獣医学 教育研究機関は, 野生動物と関わる生態学, 生物学, 倫理学, 社会学, 心理学分野などと共司して, 野生動物の安楽殺処分に 関する教育や研究をさらに進め, 社会から望まれる人材の育成 やガイドラインの整備に貢献する必要があるだろう。

\section{要 約}

安楽死とは, 苦痛がない, または苦痛が最小限の死である。 わが国では動物愛護管理法で動物の人道的な殺処分に関する規 定がなされているが, 対象は家庭動物, 展示動物, 産業動物（畜 産動物), 実験動物などの人の飼養に関わる動物であり, 野生
動物の殺処分について定める法律は整備されていない。しかし, 現実的には, 被害軽減のための個体数調整, 特定外来生物の防 除, 野生動物救護, 調查・研究などにおいて, 野生動物の殺処 分が必要な場面は多い。野生動物の命を奪うことの精神的ス卜 レスや処分に対する社会的圧力に耐え, 安楽殺処分に対する説 明責任を果たすためには，動物への苦痛が最小限の方法を実施 することが不可欠である。今後, 野生動物の適切な安楽殺処分 のためのガイドラインの整備や優れた人材の育成が望まれる。

キーワード : 安楽殺処分, 野生動物, ガイドライン

\section{引用文献}

1. 動物処分法関係専門委員会. 動物の処分方法に関する指針の解説.1996. 日本獣医師会.

2. Amass KD, Beaver BV, Bennet BT, et al.2001.2000 Report of the AVMA Panel on Euthanasia. J. Am. Vet. Med. Assoc. 218:669-696.

3. American Veterinary Medical Association. 2007. AVMA Guidelines on Euthanasia.http://www.avma.org/issues/animal_welfare/euthanasia.pdf.

4. 野生動物救護ハンドブック編集委員会. 1996. 野生動物救護ハンドブッ 夕.pp21. 文永堂出版. 東京.

5. 坪田敏男, 淺野玄. 2007.21 世紀 COE プログラム「野生動物の生態と 病態からみた環境評価」事業成果報告書（II）野生動物を指標とした環 境モニタリングプロジェクト.岐阜大学大学院連合獣医学研究科.

6. 岡野司.2009. 種の保存法と傷病鳥獣救護.pp10. 第 15 回日本野生動物 医学会大会講演要旨集. 